\title{
Profilul de rezistență la antimicrobiene al tulpinilor de Escherichia coli într-o clinică de boli infecțioase
}

\author{
Lucian Giubelan, Iulian Diaconescu, Livia Dragonu, Andreea Cristina Stoian, \\ Florentina Dumitrescu \\ Clinica de Boli Infecţioase, Universitatea de Medicină şi Farmacie, Craiova, România
}

\begin{abstract}
REZUMAT
Obiective. Stabilirea profilului de rezistenţă al tulpinilor de Escherichia coli (EC) izolate în Clinica de Boli Infecţioase Craiova.

Material şi metodă. Studiu retrospectiv (ianuarie 2017-decembrie 2018); EC au fost identificate cu ajutorul sistemului automat Vitek 2, care a stabilit ulterior sensibilitatea acestora la antimicrobiene (testare uzuală la 17 antibiotice, testare extinsă la alte 9); pentru fiecare tulpină, a fost calculat indicele de rezistenţă MAR (limite: 0-1); informaţiile au fost introduse într-o baza de date Excel. Au fost testate 128 de tulpini în 2017 şi 592 în 2018. Procentul de tulpini MDR a fost calculat pe baza definiţiilor internaţional acceptate.

Rezultate. Au fost identificate 720 de tulpini, marea majoritatea izolate prin urocultură (493 tulpini $-68,47 \%$ ). Date demografice: 508 tulpini $(71 \%)$ au fost izolate la subiecţi adulţi, $441(61 \%)$ la pacienţi de sex feminin, $411(57 \%$ ) la bolnavi ce trăiesc în mediul urban. Valoarea globală a MAR a fost de 0,23 (faţă de 0,32 pentru ansamblul tulpinilor germenilor Gram negativi izolaţi). Peste $80 \%$ dintre tulpinile de EC a fost sensibile la Ertapenem, Meropenem, Amikacină, Polimixina E, Gentamicină, Tobramicină, Cefoxitin; sensibilităţi între 60 şi $79 \%$ au fost observate pentru Cefepimă, Ceftriaxonă, Ciprofloxacină, Ceftazidimă, Levofloxacin, Imipenem, Nitrofurantoin, Cefazolin, iar între 40 şi 59\% pentru Trimetoprim-Sulfametoxazol şi Minociclină. Sub 39\% dintre tulpini sunt sensibile la Ampicilină ( \pm Sulbactam), Piperacilină ( \pm Tazobactam), Ticarcilină ( \pm Acid clavulanic), Aztreonam, Pefloxacină. Rezistenţa la principalele clase de antibiotice este în concordanţă cu datele europene şi naţionale, cu excepţia unui procent mult mai mare de tulpini rezistente la carbapeneme. Peste $50 \%$ dintre izolate sunt multidrog-rezistente; $48,3 \%$ dintre tulpini provin din surse în care există un contact important cu substantele antimicrobiene.

Concluzii. Peste $80 \%$ dintre tulpinile izolate sunt sensibile la Ertapenem, Meropenem, Amikacină, Polimixina E, Gentamicină, Tobramicină, Cefoxitin; un procent de peste 4,5\% dintre tulpini demonstrează rezistenţă la clasa carbapenemelor; peste $50 \%$ dintre izolate sunt multidrog-rezistente; $48,3 \%$ dintre tulpini provin din surse în care există un contact important cu substanţele antimicrobiene.
\end{abstract}

Cuvinte cheie: Escherichia coli, rezistenţă la antimicrobiene, MAR

\section{INTRODUCERE}

Escherichia coli (EC) este o bacterie Gram negativă (BGN) importantă în patologia umană, generând o paletă largă de infecţii (în principal urinare şi gastrointestinale, dar şi infecţii sistemice, meningeale sau pulmonare). Din punct de vedere epidemiologic, bacteria este capabilă să genereze epidemii de amploare, cum ar fi cea din 2011 (aproape 4.000 de cazuri şi 53 de decese) [1-3].
Rezistenţa la substanţele antimicrobiene este o problemă importantă de sănătate publică la nivel global, recunoscută ca atare de către Organizaţia Mondială a Sănătăţii (OMS) care, în septembrie 2016, a convocat o Adunare Generală dedicată în întregime acestui subiect, ocazie cu care a fost lansat un plan global de acţiune împotriva rezistenţei la antimicrobiene [4]. În 2017, OMS a publicat o listă de 12 bacterii pentru care este nevoie urgentă de dezvoltare de noi 
antibiotice; printre acestea, la prioritatea 1 (necesitate critică) se află enterobacteriaceele (din care face parte şi EC) producătoare de betalactamaze cu spectru extins şi carbapenemaze [5]. Centrul European pentru Prevenţia şi Controlul Bolilor (ECDC) publică periodic rapoarte privind rezistenţa la antibiotice pentru principalele bacterii ,problematice“; ultimul raport a fost publicat în 2019 şi analizează situaţia pană la sfârşitul anului anterior [6].

La nivel naţional, proiectul CARMIN-ROM a publicat până în prezent 6 rapoarte (ultimul în 2019, analizând datele disponibile până la sfârşitul lui 2017), în care analizează aspecte de antibiotico-rezistenţă [7].

Pentru clinicieni, este importantă cunoaşterea rezistenței generale la antibiotice a tulpinilor de EC în aria în care aceştia îşi desfăsoară activitatea, pentru un răspuns terapeutic rapid şi adecvat.

\section{OBIECTIV}

Stabilirea profilului de rezistenţă al tulpinilor de Escherichia coli (EC) izolate în Clinica de Boli Infecţioase Craiova (din cadrul Spitalului de Boli Infecţioase şi Pneumoftiziologie „Victor Babeş“).

\section{MATERIAL ŞI METODĂ}

Am efectuat un studiu retrospectiv (ianuarie 2017-decembrie 2018) bazat pe datele din registrul laboratorului spitalului. BGN şi, în particular, EC au fost identificate $\mathrm{cu}$ ajutorul sistemului automat Vitek 2 , care a stabilit ulterior sensibilitatea acestora la antimicrobiene; testarea uzuală a fost făcută la 17 antibiotice $-97,08 \%$, testare extinsă pentru alte 8 substanţe antimicrobiene $-1,38 \% ; 10$ tulpini $-1,38 \%$ au fost testate la 16 , iar o tulpină $-0,13 \%$ la 14 antibiotice; pentru fiecare tulpină a fost calculat indicele de rezistenţă MAR (limite: 0-1). Au fost testate 128 de tulpini în 2017 şi 592 în 2018. Pentru analiză a fost alcătuită o bază de date Excel.

\section{REZULTATE}

$\mathrm{Au}$ fost identificate 720 de tulpini (dintr-un total de 1358 de tulpini de BGN, EC fiind cea mai importantă bacterie din acest grup - 53,01\%).

Date demografice: vârsta mediană a bolnavilor a fost de 53 de ani (cu limite între $<1$ an şi 94 ani); 508 tulpini (71\%) au fost izolate la subiecţi adulţi, 441
(61\%) la pacienţi de sex feminin, 411 (57\%) la bolnavi care trăiesc în mediul urban.

Marea majoritate a EC au fost izolate prin urocultură (493 tulpini - 68,47\%). O situaţie exactă a produselor patologice din care s-a izolat bacteria este prezentată în tabelul 1. De menţionat că, la pacienţii pediatrici, EC nu a fost izolată decât din probe de urină sau fecale. Niciun pacient adult nu a avut coprocultură pozitivă cu EC.

TABEL 1. Tipul şi numărul de probe din care s-a izolat EC

\begin{tabular}{|l|c|}
\hline Produs patologic & Nr. probe \\
\hline Urocultură & 493 \\
\hline Coprocultură & 113 \\
\hline Spută & 79 \\
\hline Hemocultură & 22 \\
\hline Secreţie plagă & 4 \\
\hline Aspirat bronşic & 3 \\
\hline Secreţie vaginală & 3 \\
\hline Lichid pericardic & 1 \\
\hline Secreţie canulă & 1 \\
\hline Secreţie sondă urinară & 1 \\
\hline
\end{tabular}

Profilul de rezistenţă al EC pentru un anumit antibiotic este prezentat în tabelul 2.

Peste $80 \%$ dintre tulpinile de EC au fost sensibile la Ertapenem, Meropenem, Amikacină, Polimixina E, Gentamicină, Tobramicină, Cefoxitin; sensibilităţi între 60 şi $79 \%$ au fost observate pentru Cefepimă, Ceftriaxonă, Ciprofloxacină, Ceftazidimă, Levofloxacin, Imipenem-cilastatin, Nitrofurantoin, Cefazolin, iar între 40 şi 59\% pentru Trimetoprim-Sulfametoxazol şi Minociclină. Sub 39\% dintre tulpini sunt sensibile la Ampicilină ( \pm Sulbactam), Piperacilină ( \pm Tazobactam), Ticarcilină ( \pm Acid clavulanic), Aztreonam, Pefloxacină. În figura 1 este prezentat grafic profilul de sensibilitate al tulpinilor de EC.

Valoarea globală a MAR a fost de 0,23 (faţă de 0,32 pentru ansamblul tulpinilor germenilor Gram negativi izolaţi - date nepublicate). În figura 2 este reprezentată grafic distribuţia tulpinilor de EC în funcţie de valorile fracţiunile MAR.

În tabelul 3 este reflectată variaţia procentului de tulpini de EC rezistente la diferitele clase de antibiotice în doi ani consecutivi (2017 şi 2018).

\section{DISCUŢII}

Rezistenţa EC la aminopeniciline în Uniunea Europeană (UE) s-a situat la un nivel ridicat în 2018 (în medie 57,4\%), România aflându-se peste această 
TABEL 2. Profilul de rezistenţă al tulpinilor de EC în funcţie de antibioticul testat

\begin{tabular}{|c|c|c|c|c|c|c|}
\hline Antibiotic & $s$ & $\mathbf{i}$ & $r$ & $s \%$ & i\% & $\mathrm{r} \%$ \\
\hline Amikacina & 681 & 27 & 11 & 94,7 & 3,8 & 1,5 \\
\hline Ampicilina & 220 & 19 & 474 & 30,9 & 2,7 & 66,5 \\
\hline Ampicilina-Sulbactam & 296 & 99 & 317 & 41,6 & 13,9 & 44,5 \\
\hline Aztreonam* & 6 & 3 & 8 & 35,3 & 17,6 & 47,1 \\
\hline Cefazolin & 450 & 0 & 262 & 63,2 & 0,0 & 36,8 \\
\hline Cefepima & 567 & 64 & 82 & 79,5 & 9,0 & 11,5 \\
\hline Cefo ? & 612 & 21 & 80 & 85,8 & 2,9 & 11,2 \\
\hline Ce azidim & 554 & 102 & 64 & 76,9 & 14,2 & 8,9 \\
\hline Ce xoß̉a & 557 & 31 & 124 & 78,2 & 4,4 & 17,4 \\
\hline Cipr xacina & 557 & 5 & 156 & 77,6 & 0,7 & 21,7 \\
\hline Ertapenem & 689 & 0 & 24 & 96,6 & 0,0 & 3,4 \\
\hline Gentamicina & 640 & 5 & 75 & 88,9 & 0,7 & 10,4 \\
\hline Imipenem-cilasta & 13 & 0 & 4 & 76,5 & 0,0 & 23,5 \\
\hline Lev xacina & 549 & 4 & 163 & 76,7 & 0,6 & 22,8 \\
\hline Meropenem & 688 & 6 & 25 & 95,7 & 0,8 & 3,5 \\
\hline Minociclina* & 8 & 4 & 4 & 50,0 & 25,0 & 25,0 \\
\hline Nitrofurantoin & 521 & 152 & 37 & 73,4 & 21,4 & 5,2 \\
\hline Pe x国cina* & 5 & 0 & 10 & 33,3 & 0,0 & 66,7 \\
\hline Piperacilina & 237 & 8 & 474 & 33,0 & 1,1 & 65,9 \\
\hline Piperacilina-Tazobactam* & 6 & 5 & 6 & 35,3 & 29,4 & 35,3 \\
\hline Polimixina $E^{*}$ & 16 & 0 & 2 & 88,9 & 0,0 & 11,1 \\
\hline Ticarcilina* & 3 & 0 & 14 & 17,6 & 0,0 & 82,4 \\
\hline Ticarcilina-Acid clavulanic* & 1 & 19 & 0 & 5,0 & 95,0 & 0,0 \\
\hline Tobramicina & 629 & 4 & 87 & 87,4 & 0,6 & 12,1 \\
\hline Trimetoprim-Sulfametoxazol & 442 & 0 & 275 & 61,6 & 0,0 & 38,4 \\
\hline
\end{tabular}

Legenda: $s=$ sensibil, $i=$ intermediar, sensibilitate dependentă de doză, $r=$ rezistent; * $=$ testare extinsă

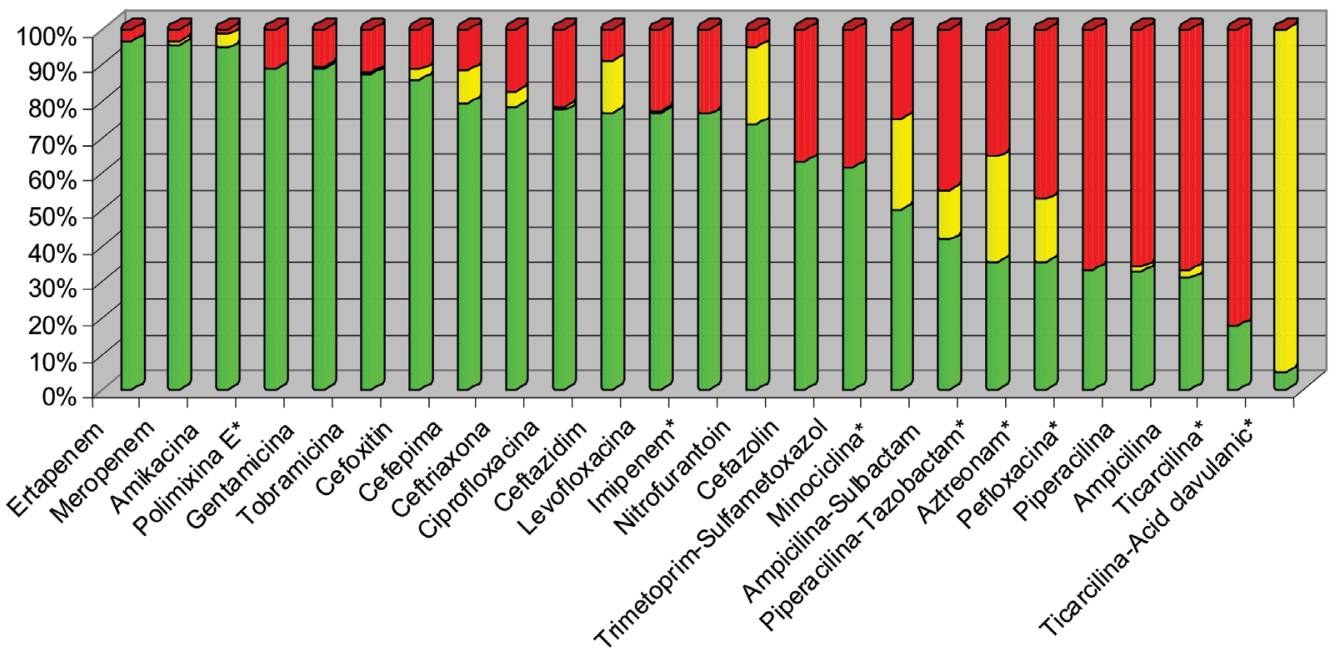

$\square S \square I \square R$

FIGURA 1. Profilul de sensibilitate la antibiotice a tulpinilor de EC izolate. Legenda: $S=$ sensibil (verde), $I=$ intermediar sensibil, sensibil în funcţie de doză (galben), $R$ = rezistent (roşu)

valoare $(62,2 \%$, locul 8 în UE), dar în scădere faţă de 2017 (68,2\%), procent confirmat şi de către studiul
CARMIN-ROM 2017 (68,7\%) [6,7]. În clinica craioveană, procentul de rezistenţă la aminopeniciline a 
MAR Escherichia coli



Fractiunea MAR

FIGURA 2. Distribuţia tulpinilor de EC în funcţie de valorile fracţiunile MAR

TABEL 3. Procentul tulpinilor rezistente la diferitele clase de antimicrobiene, 2017 vs. 2018

\begin{tabular}{|c|c|c|c|c|c|}
\hline & AminoP & CEF 3 & FQ & AG & CarbaP \\
\hline \multicolumn{5}{|c|}{2017} \\
\hline total EC & 128 & 128 & 128 & 128 & 128 \\
\hline $\mathbf{r}$ & 90 & 32 & 30 & 11 & 6 \\
\hline$\%$ & 70,31 & 25,00 & 23,44 & 8,59 & 4,69 \\
\hline \multicolumn{5}{|l|}{2018} \\
\hline total EC & 592 & 592 & 592 & 592 & 592 \\
\hline r & 384 & 100 & 134 & 82 & 27 \\
\hline$\%$ & 64,86 & 16,89 & 22,64 & 13,85 & 4,56 \\
\hline
\end{tabular}

Legenda: $A$ mino $P=$ aminopeniciline, $C E F 3=$ cefalosporine de generatia $a$ 3- $a$,

$F Q=$ fluorochinolone,$A G=$ aminoglicozide, CarbaP $=$ carbapeneme, $E C=$ Escherichia coli, $r=$ (nr. tulpini) rezistente (la antimicrobiene)

fost de 70,31\% în 2017 (90 tulpini rezistente dintr-un total de 128 testate la Ampicilină şi Ampicilină/Sulbactam), respectiv 64,86\% în 2018 (384 tulpini rezistente din 592 testate), valori ce se suprapun peste cele prezentate anterior. De remarcat faptul că adăugarea inhibitorului de betalactamază (Sulbactam) nu a influenţat profilul de rezistenţă, toate tulpinile testate fiind fie sensibile, fie rezistente la ambele substanţe antimicrobiene.

În ceea ce priveşte rezistenţa la cefalosporine de generaţia a 3 -a a fost în medie de $15,1 \%$ la nivelul UE (2018), în timp ce România a ocupat locul 7, cu o valoare medie de 20,2\% (în scădere uşoară faţă de 2017 - 22\%); conform studiului CARMIN-ROM, în 2017 rezistenţă EC la această clasă a fost de 20,1\% [6,7]. Datele obţinute în urma prezentului studiu relevă un nivel mediu al rezistenţei de 25\% în 2017 (32 de tulpini testate, rezistente la Ceftriaxonă, Ceftazidim sau la ambele, dintr-un total de 128 de tulpini testate) şi de 16,84\% în 2018 (100 de tulpini rezistente dintr-un total de 592). Este improbabil ca această scădere să fie efectul unor politici de utilizare a antimicrobienelor, ci, mai degrabă, reflectă o îmbunătăţire a situaţiei ca urmare a unui număr mai mare de teste efectuate.

Rezistenţa EC la fluorochinolone a avut o valoare medie de 25,3\% per ansamblul UE, România înregistrând un procent peste aceasta (locul 11), în creştere de la 26,4\% (2017) la 29,1\% (2018); procentul din 2017 este confirmat şi de către studiul CARMIN-ROM $(28,4 \%)[6,7]$. Clinica din Bănie se situează sub aceste valori $(23,42 \%$ în 2017 - 30 tulpini rezistente la Ciprofloxacin, Levofloxacin sau ambele, dintr-un 
total de 128 tulpini testate, respectiv 22,63\% în 2018, 134 de bacterii rezistente din 592 testate).

Referitor la rezistenţa la aminoglicozide a bacteriei studiate, nivelul mediu european a fost de $15,9 \%$, România ocupând locul $10 \mathrm{cu}$ o valoare procentuală de 15,2 în 2017, în scădere la 12,8 pentru 2018; procentul din 2017 este confirmat şi de către studiul multicentric românesc $(15,9 \%)$ [6,7]. Datele obţinute de către noi arată o valoare procentuală de 8,59\% în 2017 (11 tulpini rezistente la Amikacină, Gentamicină, Tobramicină sau la combinaţii ale acestora, dintr-un total de 128 de tulpini testate), în creştere la $13,85 \%$ în 2018 (82 de tulpini rezistente din 592 testate).

Pentru anul 2018, procentul de rezistenţă al EC la carbapeneme în UE este subunitar, cu excepţia Greciei, Bulgariei şi Ciprului; studiul CARMIN-ROM a identificat doar două tulpini rezistente din 511 testate $[6,7]$. Datele noastre arată o situaţie diferită şi îngrijorătoare, procentul de rezistenţă la Meropenem, Ertapenem sau la ambele fiind de 4,62 în 2017, respectiv 4,56 în 2018. Din cauza numărului mic de tulpini testate, nu am luat în considerare datele pentru Imipenem-cilastatin.

La nivel mondial, au fost descrise tulpini EC rezistente la polimixine [8-10], această clasă de antibiotice fiind considerată o ultimă linie de apărare împotriva

\section{BIBLIOGRAFIE}

1. Frank C, Werber D, Cramer JP et al. Epidemic profile of Shiga-toxinproducing Escherichia coli O104:H4 outbreak in Germany. N Engl J Med. 2011;365(19):1771-1780.

2. Altman $M$, Wadl $M$, Altman $D$ et al. Timelines of surveillance during outbreak of Shiga toxin-producing Escherichia coli, Germany, 2001. Emerg Infect Dis. 2011;17(10):1906-1909.

3. Buchholz U, Bernard H, Werber D et al. German outbreak of Escherichia coli 0104:H4 associated with sprouts. N Engl J Med. 2011;365:1763-1770.

4. WHO. 2015 Global action plan on antimicrobial resistance, available at: https://www.who.int/antimicrobial-resistance/publications/ global-action-plan/en/.

5. WHO. 2017 WHO publishes list of bacteria for which new antibiotics are urgently needed, available at: https://www.who.int/news-room/ detail/27-02-2017-who-publishes-list-of-bacteria-for-which-newantibiotics-are-urgently-needed.

6. ECDC. 2019 Surveillance of antimicrobial resistance in Europe 2018, available at: https://www.ecdc.europa.eu/sites/default/files/ documents/surveillance-antimicrobial-resistance-Europe-2018.pdf.

7. Popescu GA, Şerban R, Niculcea A. 2019 CARMIN-ROM 2017 (Consumul de antibiotice, rezistenţa microbiană şi infecţiile asociate asistenţei medicale (nosocomiale) în România - 2017), 41-42, available at: https://www.cnscbt.ro/index.php/analiza-date-
BGN [11]. Au fost identificate în clinica noastră două tulpini rezistente la Colistin, dintr-un număr de 16 teste. Ambele tulpini au demonstrat însă sensibilitate la alte antimicrobiene.

În conformitate cu criteriile de definiţie pentru multirezistenţă (MDR) şi rezistenţă extinsă la antimicrobiene (XDR) [12], am identificat un procent de $51,94 \%$ din tulpinile EC ca fiind MDR, dar nu am înregistrat nicio tulpină XDR.

Prin similaritate cu criteriile definite de Krumperman [13], am identificat 348 de tulpini EC $(48,33 \%)$ cu un indice MAR de peste 0,2 . Acest fapt sugerează că aproape jumătate dintre tulpinile analizate provin din surse cu expunere importantă la antibiotice (cel mai probabil intraspitaliceşti).

\section{CONCLUZII}

Peste $80 \%$ dintre tulpinile EC izolate sunt sensibile la Ertapenem, Meropenem, Amikacină, Polimixina E, Gentamicină, Tobramicină, Cefoxitin; peste 4,5\% dintre tulpini demonstrează rezistenţă la clasa carbapenemelor; peste $50 \%$ dintre izolate sunt multidrogrezistente; $48,3 \%$ dintre tulpini provin din surse în care există un contact important cu substanţele antimicrobiene.

Conflict of interest: none declared Financial support: none declared

supraveghere/infectii-nosocomiale-1/1309-consumul-de-antibioticerezistenta-microbiana-si-infectii-asociate-asistentei-medicalenosocomiale-in-romania-2017/file.

8. Yin W, Li H, Shen Y et al. Novel plasmid-mediated Colistin resistance gene mcr-3 in Escherichia coli. mBio. 2017;8(3):e00543-17.

9. Mediavilla JR, Patrawalla A, Chen L et al. Colistin- and Carbapenemresistant Escherichia coli harboring mcr-1 and blaNDM-5, causing a complicated urinary tract infection in a patient from United States. mBio. 2016;7(4):e001191-16.

10. Carattoli A, Villa L, Feudi $C$ et al. Novel plasmid-mediated Colistin resistance mcr-4 gene in Salmonella and Escherichia coli, Italy 2013, Spain and Belgium, 2015 to 2016. Euro Surveill. 2017;22(31):30589.

11. El-Sayed Ahmed MAEG, Zhang LL, Shen C et al. Colistin and its role in the Era of antibiotic resistance: An extended review (2000-2019). Emerg Microbes Infect. 2020;9(1):868-885.

12. Magiorakos AP, Srinivasan A, Carey RB et al. Multidrug-resistant, extensively drug-resistant and pandrug-resistant bacteria: an international expert proposal for interim standard definitions for acquired resistance. Clin Microbiol Infect. 2012; 18:268-281.

13. Krumperman $\mathrm{PH}$. Multiple antibiotic resistance indexing of Escherichia coli to identify high-risk sources of fecal contamination of foods. Appl Environ Microbiol. 1983;46(1):165-170. 